\title{
Comparison of total content of zinc and arsenic in soils of Średzka Upland and Wrocław ice-marginal Valley
}

\author{
Porównanie zawartości cynku i arsenu w glebach \\ Wysoczyzny Średzkiej i Pradoliny Wrocławskiej
}

\begin{abstract}
*Prof. dr hab. inż. Jarosław Kaszubkiewicz, mgrinż. Ewa Pora, dr inż. Dorota
Kawałko, dr inż. Paweł Jezierski, dr inż. Bernard Gałka, Department of Soil

Sciences and Environmental Protection. Wroclaw University of Environmen-

tal and Life Sciences, Grunwaldzka 53 St., 50-357 Wroclaw, Poland; phone:

+48 7132056 25; e-mail: jaroslaw.kaszubkiewicz@up.wroc.pl
\end{abstract}

Keywords: heavy metals, soil, Średzka Upland, Wrocław ice-marginal Valley

Słowa kluczowe: metale ciężkie, gleba, Wysoczyzna Średzka, Pradolina Wrocławska

\section{Abstract}

The aim of this study was to demonstrate that alluvial sediments of Wrocław ice-marginal Valley are characterized by higher concentrations of metallic elements in relation to the adjacent areas of different soil cover genesis.

Studies of zinc and arsenic content in soils were carried out in six municipalities of Średzki district. A total of 117 soil samples from arable land was collected: 80 from Średzka Upland and 37 from Wrocław ice-marginal Valley.

The process of accumulation of heavy metals in alluvial sediments in the Wrocław ice-marginal Valley is so effective that, despite the heavier grain size composition of the soil cover immediately adjacent to Średzka Upland, zinc and arsenic concentrations are higher in the alluvial soils.

(C) IOŚ-PIB

\section{Streszczenie}

Celem badań było wykazanie, że osady aluwialne Pradoliny Wrocławskiej charakteryzuja się podwyższoną koncentracją pierwiastków metalicznych w stosunku do przyległych obszarów o odmiennej genezie pokrywy glebowej. Badania zawartości cynku i arsenu w glebach prowadzono na terenie 6 gmin powiatu średzkiego. Pobrano 117 próbek glebowych z gruntów ornych, z czego 80 znajdowało się na Wysoczyźnie Średzkiej, a 37 na terenie Pradoliny Wrocławskiej. Proces kumulacji metali ciężkich w osadach aluwialnych na terenie Pradoliny Wrocławskiej jest na tyle efektywny, że pomimo cięższego składu granulometrycznego pokrywy glebowej bezpośrednio przylegającej do niej Wysoczyzny, koncentracje cynku i arsenu są wyższe w glebach aluwialnych.

\section{INTRODUCTION}

Trace elements are one of the many factors which in high concentration may pose a risk for living organisms [Kabata-Pendias, Pendias 1999]. In soils, increased concentration of elements, including trace elements, poses a threat to plants through the possibility of their inclusion into the food chain [Karczewska i in. 2008]; therefore, their content requires constant control and monitoring [Karczewska, Kabała 2010]. Areas of different origins differ in geochemical background. It is connected with the bedrock on which it depends on the natural content of trace elements in soil [KabataPendias, Pendias 1999]. The problem of soil pollution with heavy metals relates mainly to industrial areas or regions in the vicinity of the old sources of emissions [Kaszubkiewicz, Kawałko 2009]. Odra River is a receiver of treated and untreated sewage coming from uncontrolled sources [Głosińska, Siepak 2007]. The concentration of harmful substances in sediments is many times higher than in the water [Dąbrowska 2011]. Accelerating factor of sediments accumulation is deforestation of catchment area and their change on arable land [Ciszewski, Czajka 2009]. The soils located along the river banks can immobilize pollution from alluvial sediments, which are carriers of heavy metals [Pisarek 2008]. Surface water sediments are formed from organic and inorganic substances as well as mineral and organic suspension moved into the water from surface flow, industrial and municipal sewage [Nocoń 2009]. In addition, trace elements may get into the soil with atmospheric fallout of dust and rain [Kabata-Pendias, Pendias 1999], so regions distant from contamination sources may exhibit elevated contents of metallic elements due to longdistance atmospheric transport [Amundsen et al. 1992].

The aim of this study was to demonstrate that alluvial sediments of Wrocław ice-marginal Valley are characterized by higher concentrations of metallic elements in relation to the adjacent areas of different soil cover geneses.

\section{OBJECT AND RESEARCH METHODS}

\subsection{Research object}

Średzka Upland has an area of about $600 \mathrm{~km}^{2}$. It is moraine-outwash plain with monadnocks moraine and kame between Kaczawa and Bystrica valleys and its tributary Strzegomka [Kondracki 2002]. On Średzka Upland, the municipalities are as follows: Malczyce, Miękinia, Kostomłoty, Udanin and Środa Śląska. The area of Średzka Upland is occupied by the soils formed from loess-like clays underlain by glacial forms composed of silt loam [Stuczyński 2007]. On Wrocław ice-marginal Valley are municipalities: Malczyce, Miękinia and Środa Śląska. This area is dominated by the soils 
resulting from the holocene river sediments (alluvial) and river sands with a particle size of clay [Stuczyński 2007].

Studies of zinc and arsenic content in soils were carried out in six municipalities of Średzki district. A total of 117 soil samples from arable land were collected: 80 from Średzka Upland and 37 from Wrocław ice-marginal Valley.

\subsection{Methodology of field work}

Material for the study was collected from a depth of $0-30 \mathrm{~cm}$ of the few places directly adjacent to the point of the test (located at a distance of less than $5 \mathrm{~m}$ ). To control the depth, samples were taken with the use of soil core sampler. The samples were mixed directly in the field, and possible excess was removed. Position of the point at which the sample was collected was determined by a GPS technics. The test results are shown in the numerical map.

\subsection{Samples preparation for testing}

For laboratory tests, soil material was dried at room temperature. In determining the proportion of a particle size of soil skeleton, samples were sieved through a sieve with a mesh diameter of 2 and $1 \mathrm{~mm}$. Separated in this way, the fine earth $(<1 \mathrm{~mm})$ was subjected to further analysis.

\subsection{Laboratory tests}

Soil research included:

- Granulometric composition by aerometric-sieve method compatible with the standards PN-R-04032 i PN-R-04033 (1998).

- Soil reaction ( $\mathrm{pH}$ in distilled water and $1 \mathrm{M} \mathrm{KCl}$ - by potentiometry), compatible with the standard PN-ISO 10390:1997.

- Total forms of zinc content in the soil by AAS technique after mineralization in aqua regia (according to PN-ISO 11047; 2001 and PN-ISO 11466:2002.

- Determination of arsenic by GF AAS after mineralization in aqua regia.

For the assessment of the correctness of the determinations, certified reference materials and internal standards were used.

\section{RESULTS AND DISCUSSION}

Soils located in Średzka Upland belonged mainly to granulometric groups of sandy silt (50\%) and sandy loam (20\%). Less frequently, loamy sand $(7.5 \%)$ and sand $(3.8 \%)$ (Table 1$)$. The average content of clay fraction $(<0.002 \mathrm{~mm})$ was $6.1 \%$, median $5.5 \%$ and standard deviation $4.4 \%$. Silt fraction was the highest. Its averaged content was $48.8 \%$, median $50.5 \%$ and standard deviation $17.7 \%$ (Table 2).

Soils located in Wrockaw ice-marginal Valley belonged mainly to granulometric groups of loam (27\%) and sandy silt (24\%) (Table 1). They were characterized by a higher average content of clay parts (average 10.9\%, median 9\%, standard deviation $7.7 \%$ ) and lower than on Średzka Upland part of the silt content (average $37.7 \%$, median $35 \%$, standard deviation $15.4 \%$ ) (Table 2).

The significance level for the hypothesis of no difference between the content of silt fraction in both areas was $p=1.4 \times 10^{-2}$, while the hypothesis of no difference between the content of the clay fraction significance level was $p=3.1 \times 10^{-5}$. Sand fraction content did not differ in both areas in a statistical significant way. For all tested soil samples located on Średzka Upland, $\mathrm{pH}$ values measured in $1 \mathrm{M} \mathrm{KCl}$ ranged from $\mathrm{pH} 3.9$ to $\mathrm{pH} 8.0$. The average value was 6.1; the median was at similar level and amounted to 6.3 (Table 3). In terms of reaction classification, 8 examined points were found very acidic, 18 points acidic, 26 points slightly acidic, 18 points neutral and 10 points alkaline (Table 4).

For all tested soil samples located on Wrocław ice-marginal Valley $\mathrm{pH}$ values measured in $1 \mathrm{M} \mathrm{KCl}$ ranged from $\mathrm{pH} 4.5$ to $\mathrm{pH}$ 7.8. The average value was 6.1 , the median was at similar level and amounted to 6.2 (Table 3). In terms of reaction classification, 1 examined point was found very acidic, 15 points acidic, 6 points slightly acidic, 8 points neutral and 7 points alkaline (Table 4).

The zinc content(Mapno. 2) for all tested samples located on Średzka Upland ranged from $22.0 \mathrm{mg} \cdot \mathrm{kg}^{-1}$ to $157.0 \mathrm{mg} \cdot \mathrm{kg}^{-1}$ (Table 5). Average zinc content in all 80 tested samples was $40.9 \mathrm{mg} \cdot \mathrm{kg}^{-1}$. Geochemical background for this element is $7-40 \mathrm{mg} \cdot \mathrm{kg}^{-1}$ [KabataPendias, Pendias 1999]. The limit value specified in the Ordinance of the Environment Minister [Rozporządzenie 2002] on standards for soil quality, to lands from group B amounting to $300 \mathrm{mg} \cdot \mathrm{kg}^{-1}$, was therefore not exceeded in any of test points.

On Wrocław ice-marginal Valley for all tested samples, zinc content ranged from 10.2 to $466.0 \mathrm{mg} \cdot \mathrm{kg}^{-1}$ (Table 5). Average zinc content in all tested 37 samples was $61.7 \mathrm{mg} \cdot \mathrm{kg}^{-1}$. The limit value specified in the Ordinance of the Environment Minister [Rozporządzenie 2002] on standards for soil quality, to lands from group B amounting to $300 \mathrm{mg} \cdot \mathrm{kg}^{-1}$, was therefore exceeded only in point no. 62 located in the Miękinia municipality. The arsenic content (Map no. 2) for all tested samples located on Średzka Upland ranged from 2.4 to $11.5 \mathrm{mg} \cdot \mathrm{kg}^{-1}$ (Table 5 ). Average arsenic content in all tested 80 samples was $5.1 \mathrm{mg} \cdot \mathrm{kg}^{-1}$. Geochemical background for this element is $2-13 \mathrm{mg} \cdot \mathrm{kg}^{-1}[\mathrm{Ka}$ bata-Pendias, Pendias 1999].

The limit value specified in the Ordinance of the Environment Minister on standards for soil quality, to lands from group B amounting to $20 \mathrm{mg} \cdot \mathrm{kg}^{-1}$ [Rozporzadzenie 2002], was therefore not exceeded in any of test points.

On Wrocław ice-marginal Valley, for all tested samples, arsenic content ranged from 1.7 to $99.1 \mathrm{mg} \cdot \mathrm{kg}^{-1}$ (Table 5). Average arsenic content in all tested 37 samples was $10.6 \mathrm{mg} \cdot \mathrm{kg}^{-1}$. The limit value specified in the Ordinance of the Environment Minister on standards for soil quality, to lands from group B amounting to $20 \mathrm{mg} \cdot \mathrm{kg}^{-1}$ [Rozporządzenie 2002], therefore exceeded in three points: nos 37 and 38 located in Środa Ślaska municipality and point no. 85 located in Miękinia municipality.

Table 1. Number of samples belonging to different granulometric groups on Średzka Upland and Wrocław ice-marginal Valley

\begin{tabular}{|c|c|c|c|c|c|c|c|c|c|c|c|}
\hline & \multirow{3}{*}{$\begin{array}{l}\text { Number } \\
\text { of } \\
\text { samples }\end{array}$} & \multicolumn{10}{|c|}{ Granulometric group } \\
\hline & & Silt loam & Silt & $\begin{array}{l}\text { Sandy } \\
\text { silt }\end{array}$ & $\begin{array}{l}\text { Silty } \\
\text { loam }\end{array}$ & Loam & $\begin{array}{l}\text { Sandy } \\
\text { loam }\end{array}$ & $\begin{array}{l}\text { Light } \\
\text { loam }\end{array}$ & $\begin{array}{c}\text { Heavy } \\
\text { loam }\end{array}$ & $\begin{array}{l}\text { Loamy } \\
\text { sand }\end{array}$ & Sand \\
\hline & & \multicolumn{10}{|c|}{ Number of samples } \\
\hline \multicolumn{12}{|c|}{ Średzka Upland } \\
\hline $\begin{array}{l}\text { Total } \\
\text { Upland }\end{array}$ & 80 & 1 & 9 & 40 & 0 & 3 & 16 & 1 & 1 & 6 & 3 \\
\hline \multicolumn{12}{|c|}{ Wrocław ice-marginal Valley } \\
\hline $\begin{array}{l}\text { Total } \\
\text { Valley }\end{array}$ & 37 & 0 & 1 & 9 & 1 & 10 & 5 & 2 & 2 & 3 & 4 \\
\hline
\end{tabular}


Comparison of zinc and arsenic content in soils of Średzka Upland and Wrocław ice-marginal Valley was made using Student's $t$-test (Table 6). For both studied elements, the average concentrations differ significantly. The significance level for the hypothesis of no difference between the content of two elements in the studied areas was $1.6 \times 10^{-2}$ for zinc and $2.5 \times 10^{-3}$ for arsenic. Higher concentrations of these elements are observed on Wrocław ice-marginal Valley. The average content of zinc in soils of Wrocław ice-marginal Valley is $151 \%$, and arsenic $208 \%$ from contents of these elements in soils of Średzka Upland. The results are shown in Figs 3 and 4.

Due to observable deviations from the normal distribution, it was decided to compare the mean values after logarithmical transformation. The results are summarized in Table 7. Also in this case for both studied elements, the average concentrations differ significantly.

The significance level for the hypothesis of no difference between the content of both elements in studied areas was $1.1 \times 10^{-2}$ for zinc and $1.2 \times 10^{-4}$ for arsenic.

It was observed that despite the heavier composition of Średzka Upland soils, a significant higher content of discussing metals are present in Wrockaw ice-marginal Valley soils. This is connected primarily with the proximity of the river carrying alluvial sediments with high content of trace elements [Głosińska, Siepak 2007]. Similar results were received by Pisarek [2008]. As Nocoń studies shows [2009] zinc content in bottom sediments may be as high as $1900 \mathrm{mg} \cdot \mathrm{kg}^{-1}$. In the case of arsenic, classification proposed by Bojakowska gives the content of this element in contaminated sediments [2001] by $30 \mathrm{mg} \cdot \mathrm{kg}^{-1}$.

\section{CONCLUSIONS}

1. Wrocław ice-marginal Valley is the border of the occurrence of soil tracks with different granulometric compositions. On Średzka Upland, silts and sandy clays are dominating, while in the Wrocław ice-marginal Valley mainly loamy tracks are there.

2. The process of accumulation of heavy metals in alluvial sediments in the Wrocław ice-marginal Valley is so effective that, despite the heavier grain size composition of the soil cover immediately adjacent to Średzka Upland, zinc and arsenic concentrations are higher in the alluvial soils.

Table 2. Selected statistical parameters characterizing granulometric composition of soils on Średzka Upland and Wrocław icemarginal Valley

\begin{tabular}{|c|c|c|c|c|c|c|}
\hline Fraction & $\begin{array}{l}\text { Number of } \\
\text { samples }\end{array}$ & Average & Median & Minimum & Maximum & $\begin{array}{l}\text { Standard } \\
\text { deviation }\end{array}$ \\
\hline \multicolumn{7}{|c|}{ Średzka Upland } \\
\hline Sand & \multirow{3}{*}{80} & 45.1 & 42.0 & 14.0 & 86.0 & 18.9 \\
\hline Silt & & 48.8 & 50.5 & 12.0 & 84.0 & 17.7 \\
\hline Clay & & 6.1 & 5.5 & 1.0 & 29.0 & 4.4 \\
\hline \multicolumn{7}{|c|}{ Wrocław ice-marginal Valley } \\
\hline Sand & \multirow{3}{*}{37} & 51.4 & 47.0 & 24.0 & 85.0 & 17.5 \\
\hline Silt & & 37.7 & 35.0 & 10.0 & 66.0 & 15.4 \\
\hline Clay & & 10.9 & 9.0 & 1.0 & 34.0 & 7.7 \\
\hline
\end{tabular}

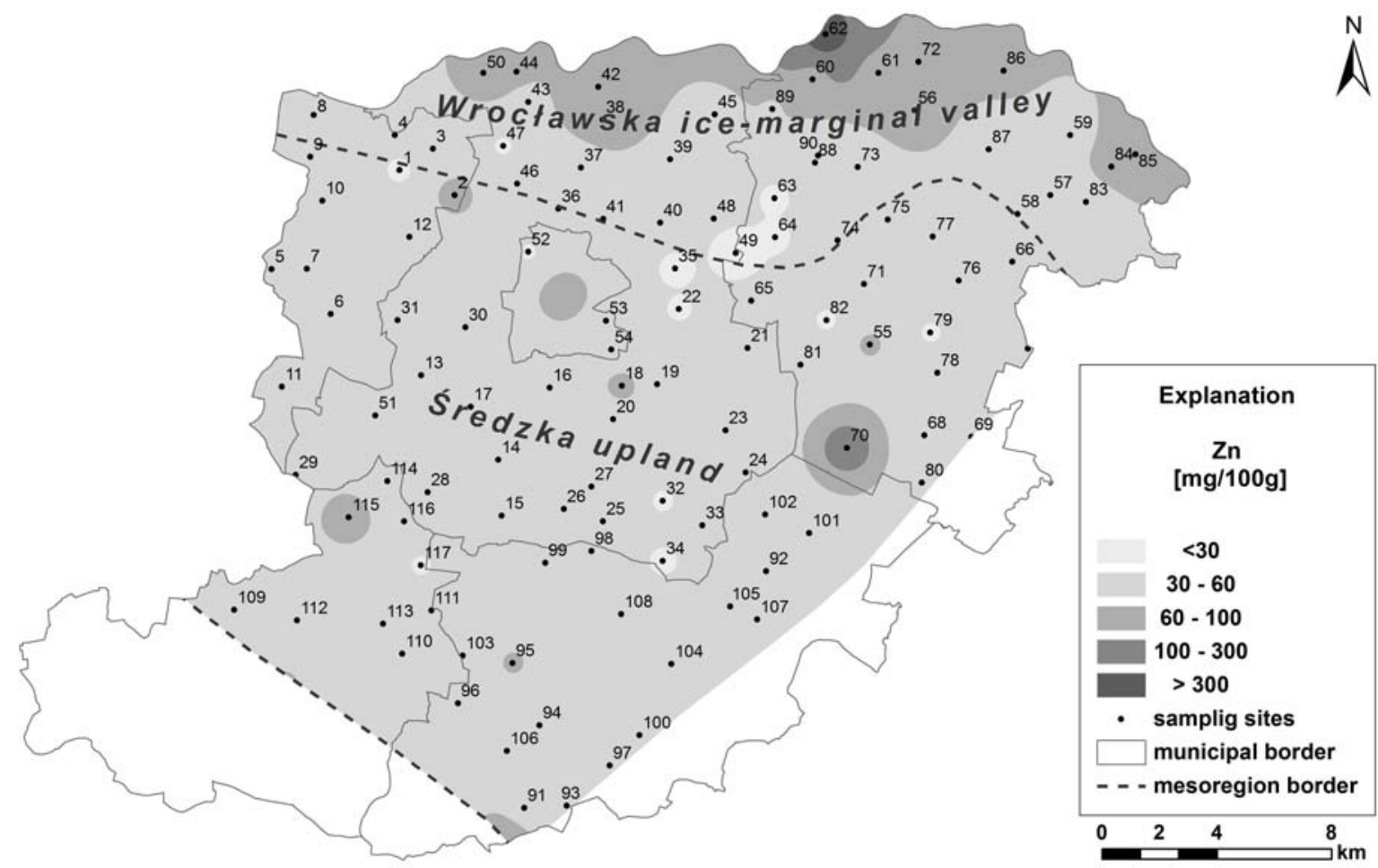

Fig. 1. The zinc content in soils of Średzka Upland and Wrocław ice-marginal Valley 
Table 3. Selected statistical parameters characterizing the soil pH of Średzka Upland and Wrocław ice-marginal Valley

\begin{tabular}{|c|c|c|c|c|c|c|c|}
\hline & \multirow{2}{*}{$\begin{array}{c}\text { Number of } \\
\text { samples }\end{array}$} & \multicolumn{6}{|c|}{ Coefficient } \\
\hline & & Minimum & Maximum & Average & Median & $\begin{array}{c}\text { Standard devia- } \\
\text { tion }\end{array}$ & Coefficient of variation \\
\hline Unit & - & \multicolumn{5}{|c|}{$\mathrm{pH}$} & [\%] \\
\hline \multicolumn{8}{|c|}{ Średzka Upland } \\
\hline Total Upland & 80 & 3.9 & 8.0 & 6.1 & 6.3 & 0.9 & 15.4 \\
\hline \multicolumn{8}{|c|}{ Wrocław ice-marginal Valley } \\
\hline Total Valley & 37 & 4.5 & 7.8 & 6.1 & 6.2 & 1.0 & 15.8 \\
\hline
\end{tabular}

Table 4. Soil reaction of Średzka Upland and Wrocław ice-marginal Valley

\begin{tabular}{|c|c|c|c|c|c|c|}
\hline & \multirow{2}{*}{$\begin{array}{l}\text { Number of } \\
\text { samples }\end{array}$} & \multicolumn{5}{|c|}{ Reaction } \\
\hline & & Very acidic & Acidic & Slightly acidic & Neutral & Alkaline \\
\hline \multicolumn{7}{|c|}{ Średzka Upland } \\
\hline Total Upland & 80 & 8 & 18 & 26 & 18 & 10 \\
\hline \multicolumn{7}{|c|}{ Wrocław ice-marginal Valley } \\
\hline Total Valley & 37 & 1 & 15 & 6 & 8 & 7 \\
\hline
\end{tabular}

Table 5. Selected statistical parameters characterizing the content of zinc and arsenic in soils of Średzka Upland and Wrockaw icemarginal Valley

\begin{tabular}{|c|c|c|c|c|c|c|c|}
\hline & \multirow[b]{2}{*}{$\begin{array}{c}\text { No. of } \\
\text { samples }\end{array}$} & \multicolumn{3}{|c|}{$\mathrm{Zn}$} & \multicolumn{3}{|c|}{ As } \\
\hline & & $\begin{array}{c}\text { Average } \\
\text { content } \\
{\left[\mathrm{mg} \cdot \mathrm{kg}^{-1}\right]}\end{array}$ & $\begin{array}{l}\text { Min-max } \\
\text { content }\end{array}$ & $\begin{array}{l}\text { No. of higher } \\
\text { than the } \\
\text { standard }\end{array}$ & $\begin{array}{c}\text { Average } \\
\text { content } \\
{\left[\mathrm{mg} \cdot \mathrm{kg}^{-1}\right]}\end{array}$ & $\begin{array}{l}\text { Min-max } \\
\text { content }\end{array}$ & $\begin{array}{c}\text { No. of } \\
\text { samples } \\
\text { higher than } \\
\text { the standard }\end{array}$ \\
\hline & Standard B & & 300 & & & 20 & \\
\hline \multicolumn{8}{|c|}{ Średzka Upland } \\
\hline Total Upland & 80 & 40.9 & $22.0-157.0$ & 0 & 5.1 & $2.4-11.5$ & 0 \\
\hline \multicolumn{8}{|c|}{ Wrocław ice-marginal Valley } \\
\hline Total Valley & 37 & 61.7 & $10.2-466.0$ & 1 & 10.6 & $1.7-99.1$ & 3 \\
\hline
\end{tabular}

Table 6. Selected statistical parameters for the comparison of Zn and As in soils of Średzka Upland and Wrocław ice-marginal Valley

\begin{tabular}{|c|c|c|c|c|}
\hline & \multicolumn{2}{|c|}{$\mathrm{Zn}$} & \multicolumn{2}{|c|}{ As } \\
\hline & Średzka Upland & $\begin{array}{c}\text { Wrocław ice-marginal } \\
\text { Valley }\end{array}$ & Średzka Upland & $\begin{array}{c}\text { Wrocław ice-marginal } \\
\text { Valley }\end{array}$ \\
\hline Average & 40.9 & 61.7 & 5.1 & 10.6 \\
\hline Standard deviation & 17.4 & 71.4 & 1.8 & 15.8 \\
\hline$p$ & \multicolumn{2}{|c|}{$1.6 \times 10^{-2}$} & \multicolumn{2}{|c|}{$2.5 \times 10^{-3}$} \\
\hline
\end{tabular}

Table 7. Selected statistical parameters for the comparison of Zn and As in soils of Średzka Upland and Wrocław ice-marginal Valley after logarithmical transformation

\begin{tabular}{|c|c|c|c|c|}
\hline & \multicolumn{2}{|c|}{$\operatorname{Ln}(\mathrm{Zn})$} & \multicolumn{2}{|c|}{$\operatorname{Ln}(A s)$} \\
\hline & Średzka Upland & $\begin{array}{c}\text { Wrockaw ice-marginal } \\
\text { Valley }\end{array}$ & Średzka Upland & $\begin{array}{c}\text { Wrockaw ice-marginal } \\
\text { Valley }\end{array}$ \\
\hline Average & 3.7 & 3.9 & 1.6 & 2.0 \\
\hline Standard deviation & 0.3 & 0.6 & 0.3 & 0.8 \\
\hline$p$ & \multicolumn{2}{|c|}{$1.1 \times 10^{-2}$} & \multicolumn{2}{|c|}{$1.2 \times 10^{-4}$} \\
\hline
\end{tabular}




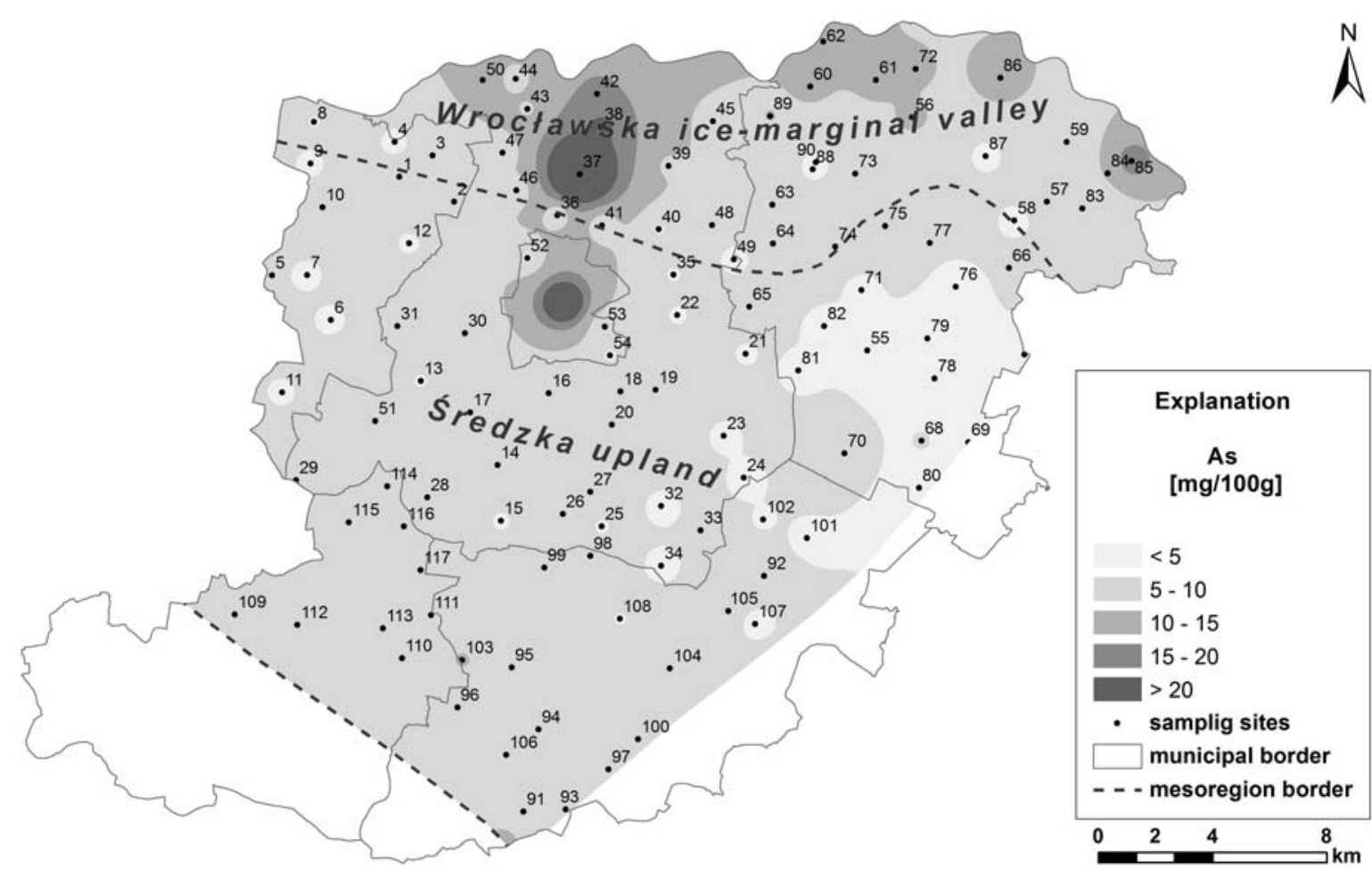

Fig. 2. The arsenic content in soils of Średzka Upland and Wrocław ice-marginal Valley

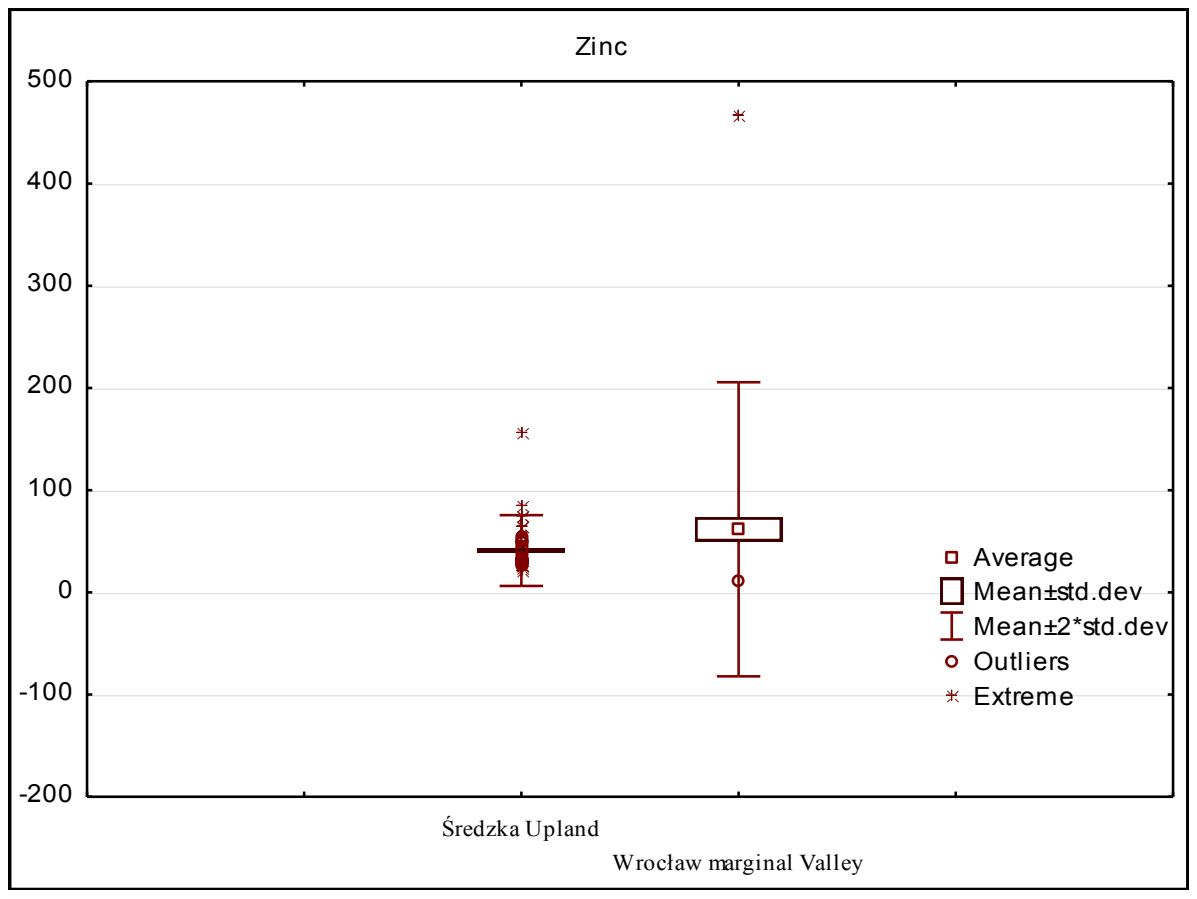

Fig. 3. The zinc content in soils of both regions 


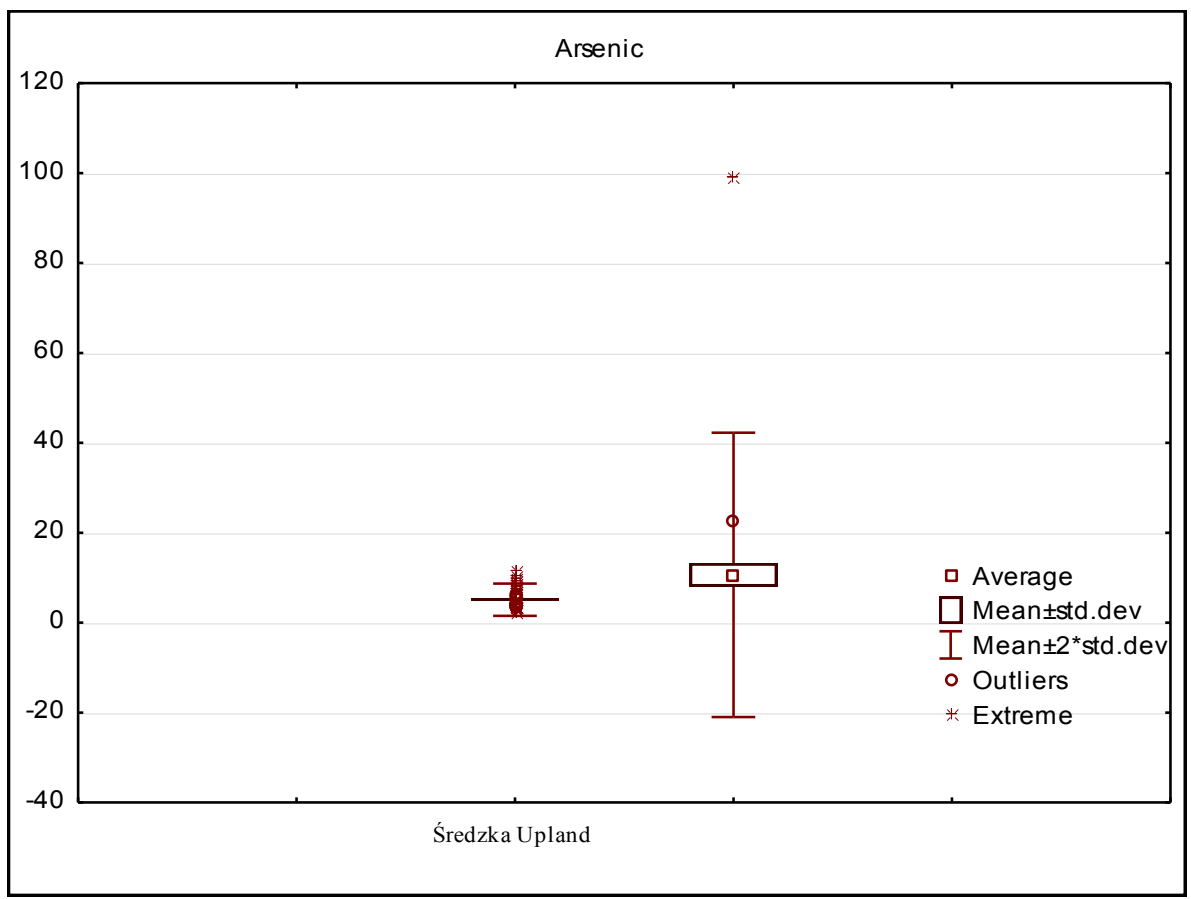

Fig. 4. The arsenic content in soils of both regions

\section{REFERENCES AND LEGAL ACT}

AMUNDSEN, C. E., HANSSEN, J. E., SEMB, A., STEINNES, E. 1992. Long-range transport of trace elements to Southern Norway. Atmospheric Environment, 26A: 1309-1324.

BOJAKOWSKA I. 2001. Kryteria oceny zanieczyszczenia osadów wodnych. Przegląd Geologiczny 49,3: 213-218.

CISZEWSKI D., CZAJKA A. 2009. Akumulacja osadów na równinach zalewowych rzek silnie zmienionych antropogenicznie: górna Wisła i Odra. Przegląd Geologiczny 57, 7: 576583.

DĄBROWSKA L. 2011. Specjacja metali ciężkich w osadach dennych zbiornika Kozłowa Górna. Ochrona Środowiska i Zasobów Naturalnych 49: 354-364.

GŁOSIŃSKA G., SIEPAK J. 2007.Zanieczyszczenie środkowej i dolnej Odry wybranymi metalami ciężkimi w latach w latach 1991-2005 na podstawie wyników monitoringu geochemicznego osadów dennych. Środkowo-Pomorskie Towarzystwo Naukowe Ochrony Środowiska 9: 167-181.

KABATA-PENDIAS A., PENDIAS H. 1999. Biogeochemia pierwiastków śladowych. PWN, Warszawa.

KARCZEWSKA A., KABAŁA C.2010.Gleby zanieczyszczone metalami ciężkimi i arsenem na Dolnym Śląsku - potrzeby i metody rekultywacji. Zeszyty Naukowe UP we Wrocławiu. Rolnictwo XCVI 576: 59-79.
KARCZEWSKAA., SPIAK Z., KABAŁA C., GAŁKA B., SZOPKAK., JEZIERSKI P., KOCAN K. 2008. Ocena możliwości zastosowania wspomaganej fitoekstrakcji do rekultywacji gleb zanieczyszczonych emisjami hutnictwa miedzi. Wyd. Zante, Wrocław.

KASZUBKIEWICZ J., KAWAŁKO D. 2009. Zawartość wybranych metali ciężkich w glebach i roślinach na terenie Powiatu Jeleniogórskiego. Ochrona Środowiska i Zadobów Naturalnych 40: 177-189.

KONDRACKI J. 2002. Geografia regionalna Polski. PWN, Warszawa.

NOCOŃ W. 2009. Metale ciężkie w osadach dennych wybranych dopływów rzeki Kłonicy. Inżynieria i Ochrona Środowiska t.12, nr 1: 65-76.

PISAREK I. 2008. Antropogeniczne wzbogacenie w metale ciężkie gleb obszarów zalewowych na terenie miasta Opola. Środkowo-Pomorskie Towarzystwo Naukowe Ochrony Środowiska 10: 645-656.

Rozporządzenie Ministra Środowiska w sprawie standardów jakości gleby oraz standardów jakości ziemi (Dz.U. 2002. Nr 165 poz. 1359).

STUCZYŃSKI T. i inni. 2007. Stan i zmiany właściwości gleb użytkowanych rolniczo $w$ województwie dolnośląskim w latach 2000-2005. IUNG, Puławy. 